\title{
IDENTIFICATION OF HOLSTEIN COWS CARRIERS OF COMPLEX VERTEBRAL MALFORMATION BY HIGH RESOLUTION MELTING CURVES (HRM)
}

(Identificação de vacas holandesas portadoras da malformação vertebral complexa através de curvas de dissociação de alta resolução - HRM)

Andrea Branda Sica ${ }^{1}$, Paula Nicolini ${ }^{2}$, María Teresa Federici ${ }^{1}$, Silvia Llambi ${ }^{3}$

\begin{abstract}
${ }^{1}$ Instituto Nacional de Investigación Agropecuaria (INIA), INIA Las Brujas, Unidad de Biotecnología; ${ }^{2}$ Universidad de La República, Centro Universitario de Tacuarembó, Instituto Superior de la Carne, Área Biología Molecular; ${ }^{3}$ Universidad de La República. Facultad de Veterinaria, Sección Genética
\end{abstract}

Corresponding author: abranda@inia.org.uy

ABSTRACT: The objective of this study was the optimization and implementation of a reliable and economical molecular screening method for the detection of the mutant allele of CVM (complex vertebral malformation, c.559G>T, SLC35A3) by HRM analysis, as well as analyzing its existence in a representative sample of Holstein cows from the Milk Genomic DNA Bank of Uruguay. The optimization of the HRM methodology in the RotorGene ${ }^{\mathrm{TM}} 6000$ equipment (Corbett Life Science, Australia) by amplification of the $79 \mathrm{bp}$ PCR products clearly differentiated the two genotypes: homozygous, wild type: GG; and heterozygous, carrier for the mutation CVM: GT (c.559G>T; SLC35A3). In the analyzed sample, the frequency of the mutant allele $(T)$ for CVM was high $(q=0.032)$, with a prevalence of carrier cows of $6.45 \%$. It is concluded that the PCR-HRM analysis is a fast, easily interpretable, low cost, and highly accurate technique for the detection of this mutation in Holstein cattle, which may be implemented in genetic selection programs.

Keywords: CVM; high-resolution dissociation curve; Holstein.

RESUMO: O objetivo deste estudo foi otimizar e implementar um sistema fiável e econômico para a detecção molecular do alelo mutante CVM (malformação vertebral complexa; c.559G>T; SLC35A3) por meio da análise HRM, assim como analisar sua presença em uma amostra representativa de vacas Holandesas do Banco de ADN do Instituto Nacional de Pesquisa Agropecuária de Uruguai. A otimização da metodologia HRM no equipamento RotorGene ${ }^{\mathrm{TM}} 6000$ (Corbett Life Science, Austrália) através da amplificação dos produtos de PCR de 79 pb permitiu diferenciar os dois genótipos: o homozigoto de tipo salvagem (GG) e o heterozigoto que presenta a mutação CVM (GT). Verificou-se que a frequência do alelo mutante (T) para CVM na amostra analisada foi alta, de $q=0,032$, enquanto que a prevalência de vacas portadoras da mutação foi $6,45 \%$. Concluiu-se que a análise por PCR-HRM é uma técnica rápida, facilmente interpretável, de baixo custo e alta precisão para a detecção dessa mutação no gado Holandês, que poderia ser implementada em programas de seleção genética.

Palavras-chave: Curvas de dissociação de alta resolução; CVM; Holandês. 


\section{INTRODUCTION}

Complex vertebral malformation (CVM, OMIA 001340-9913) is a recessive autosomal disease that causes miscarriages and perinatal problems. The single site mutation causing this disease is a substitution of Guanine ( $G$ ) by Thymine ( $T$ ) in the position 559 of exon 4 of gene SCL35A3 (c.559G>T; Thomsen et al., 2006), which plays an essential role in the development of the axial skeleton. This gene codes the UDP-Nacetylglucosamine transporter, and the mutation replaces a valine with a phenylalanine (V180F) at position 180 (Rusc and Kaminski, 2007). Thereof, the defective transporter molecule leads to vertebral malformations (Thomsen et al., 2006). VanRaden et al. (2011) confirmed that this mutation is located in position 43.412.427 bp of chromosome 3.

This disease was reported by Danish scientists as from 2000 (Agerholm et al., 2001; 2004), and its origin could be traced to the elite American bull Carlin-M Ivanhoe Bell, who received the lethal recessive mutation of the CVM disease from his father, Penstate Ivanhoe Star (Revell, 2001; Chu et al., 2008). Due to the superior performance of his daughters at lactation, this bull was worldwide widely used for the raising of dairy cattle (Agerholm, 2007; Windsor and Agerholm, 2009; Agerholm et al., 2004). Among the bulls used for artificial insemination, CVM carrier animals were identified with a very high prevalence $(10-30 \%)$ in several countries (Kearney et al., 2005; Citek et al., 2006; Thomsen et al., 2006). Since then, the disease and several CVM carriers have been identified in other countries (Revell, 2001; Duncan et al., 2001; Nagahata et al., 2002; Konersmann et al., 2003; Berglund et al., 2004; Rusc and Kaminski, 2007; Chu et al., 2008).
The high resolution melting curves analysis (HRM) is a simple an economic method, performed in closed tubes, for the analysis of PCR products (Wittwer et al., 2003). This method is based in the melting behavior of PCR products (Reed et al., 2007). It shows a high sensitivity and specificity with PCR products smaller than $400 \mathrm{bp}$ long (Reed et al., 2007). HRM has been widely used for genotyping and screening of mutations, both in human (Montgomery et al., 2004; Hung et al., 2008; Vossen et al., 2009; Vorkas et al., 2010) and animal health, particularly in cattle (Gabor et al., 2012a and 2012b; Santos et al., 2012; Federici et al., 2018).

In Uruguay, the disease has not been diagnosed, and the mutant allele has not been reported in the general cattle herd. Hence, the purpose of this study consisted in the optimization and implementation of a reliable and economic molecular screening method for detection of the mutant CVM allele (c.559G>T; SLC35A3) by HRM analysis, as well as analyzing its presence in a representative sample of Holstein cows of the Milk Genomic DNA Bank of Uruguay.

\section{MATERIALS AND METHODS}

Samples and reference material:

The analyzed cattle consisted in a representative sample of 279 secondlactation Holstein cows of 6 commercial dairy farms from different regions of Uruguay. The DNA of these samples is stored in the Milk Genomic DNA Bank of Uruguay of the Biotechnology Unit of the INIA Las Brujas as reference material for future investigation projects (INMLUdelaR-INIA agreement).

DNA extraction, concentration and quality

Genomic DNA extraction and purification from fresh blood samples 
was performed in 2008 in the Laboratory of Nuclear Techniques (Faculty of Veterinary, UdelaR) according to the salting-out and proteinase $\mathrm{K}$ digestion protocol described by Miller et al. (1988). DNA concentration was assessed with nanodrop at $260 \mathrm{~nm}$ (NanoDrop 8000 spectrophotometer, Thermo Scientific), and DNA quality was assessed by means of the OD260/OD280 relationship, between 1.8 and 2.0.

Optimization of genotyping by real-time PCR-HRM and data analysis

In order to identify the mutant allele of the CVM disease (c.559G $>\mathrm{T}$; SLC35A3), optimization of genotyping was performed by real-time PCR applying HRM in the RotorGene ${ }^{\mathrm{TM}} 6000$ (Corbett Life Science, Australia) equipment. 79 bp PCR products were amplified with the primers described by ZhiLing et al. (2015). PCR reactions were carried out on a final volume of 25 $\mu l$ with $50 \mathrm{ng}$ of genomic DNA, 1X HRMPCR Master Mix (kit Type-it ${ }^{\circ}$ HRM$P C R$, QIAGEN, Hilden, Germany), and $0.7 \mu$ of each primer (forward and reverse). The cycling program consisted in an initial denaturation of $10 \mathrm{~min}$ at 95 ${ }^{\circ} \mathrm{C}, 40$ cycles of $5 \mathrm{~s}$ at $95^{\circ} \mathrm{C}, 25 \mathrm{~s}$ at 60 ${ }^{\circ} \mathrm{C}$ and $20 \mathrm{~s}$ at $72{ }^{\circ} \mathrm{C}$, and two holds of $10 \mathrm{~s}$ at $95^{\circ} \mathrm{C}$ and $1 \mathrm{~min}$ at $45^{\circ} \mathrm{C}$, respectively. The annealing temperature was adjusted to $60^{\circ} \mathrm{C}$ with the activation of the fluorescence data in the green channel (excitation: $470 \mathrm{~nm}$; detection: $510 \mathrm{~nm}$ ). The HRM phase was adjusted with $0.1{ }^{\circ} \mathrm{C}$ increments, with a $2 \mathrm{~s}$ retention in each increment from 74.5 to $84.5^{\circ} \mathrm{C}$, with the acquisition of the fluorescence data in the green channel of HRM (excitation: $460 \mathrm{~nm}$; detection: $510 \mathrm{~nm}$ ). Analyses of the HRM curve were performed with the Rotor-Gene $Q$ vers. 2.3.1 (Build 49) software and the provided HRM algorithm. The predetermined normalization regions for the CVM single site mutation (c.559G $>\mathrm{T}$; SLC35A3) were applied. HRM data were viewed as normalized HRM curves and normalized difference graphs for the GG genotypes (homozygous, wild type) and GT (homozygous, carrier of the mutation). Genotypes of unknown samples were automatically assigned by the Rotor-Gene HRM software. The confidence threshold for accepting the genotype assigned by the software was $90 \%$. In addition, in order to confirm the precision of genotypes by HRM, 25 DNA samples were selected at random and send to the Instituto de Genética Veterinaria of the Universidad Nacional de la Plata (IGEVET-CONICET, UNLP, La Plata, Argentina) to be genotyped with the low density panel microarray ArBos $150 K$ of the Affymetryx platform. Allelic and genotypic frequencies were calculated by direct counting according to the method of Nei (1989).

\section{RESULTS AND DISCUSSION}

Figures 1 and 2 show the results of the HRM analysis of gene SLC35A3. The Rotor-Gene HRM software automatically assigned the genotypes for the mutant CVM allele (c.559G $>\mathrm{T}$; $S L C 35 A 3)$ according to the differences in the pattern of the melting curve and the melting temperature $(T m)$ of heterozygous and wild type homozygous. Figure 1 shows the different patterns of the single site mutation $G$ for $T$, showing the two genotypes. Violet curves correspond to the wild type homozygous, and the green one to the heterozygous for the mutation (that is, a normal $\mathrm{G}$ allele, and a mutated $T$ allele). The HRM methodology permitted to clearly differentiate the two genotypes of the mutant CVM allele (c.559G $>\mathrm{T}$; SLC35A3). Figure 2 shows the difference curves obtained with the HRM analysis; these curves can be differentiated by comparing the shape of the difference curves based in the 
genotypes with those of the CVM (c.559G >T; SLC35A3) carriers, which are taken as reference, clearly identifying the two genotypes: wild type homozygous (GG, violet), and heterozygous CVM carriers (GT, green). Figure 3 shows the melting curves of the negative derivatives $(-d F / d T)$ generated from unprocessed data of the HRM analysis. The peak values were 78.75 ${ }^{\circ} \mathrm{C}$ for allele $\mathrm{G}$, and $77.05^{\circ} \mathrm{C}$ for allele $\mathrm{T}$. The melting curves of the negative derivatives $(-d F / d T)$ of the heterozygous genotype were identified by peaks with a value of $78.75^{\circ} \mathrm{C}$ (Figure 3 ).

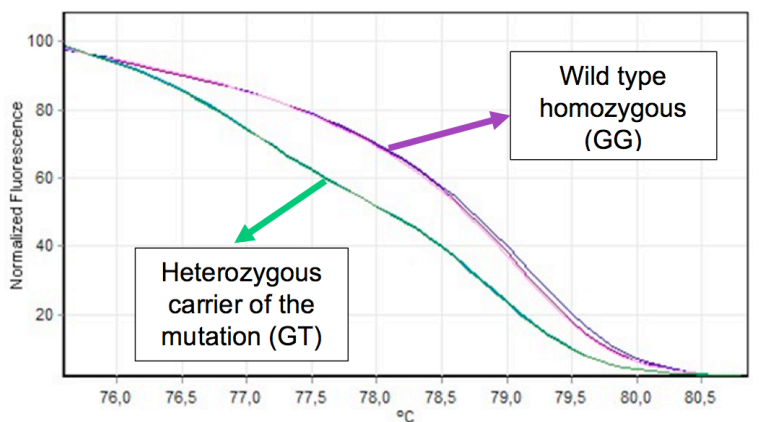

Figure 1. Graph with the normalization of the high resolution melting pattern: normalized denaturation curves obtained with the HRM analysis. Y-axis: normalized fluorescence; Xaxis: temperature $\left({ }^{\circ} \mathrm{C}\right)$. The graph shows three genetic materials of each genotype.

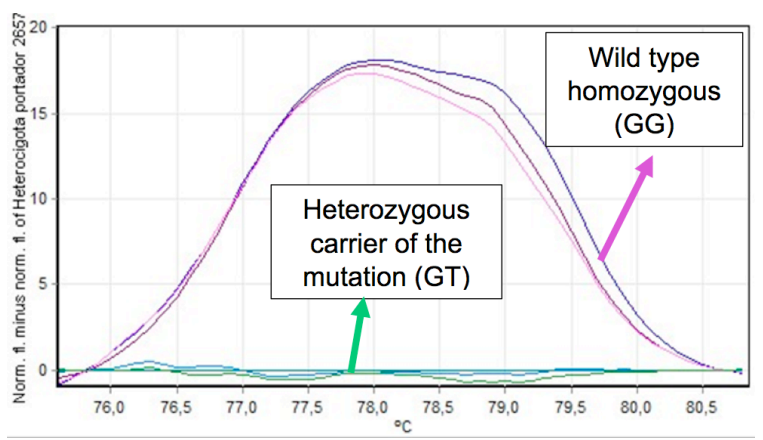

Figure 2. Graph of differences between genotypes: difference curves obtained with the HRM analysis. Y-axis: normalized fluorescence; $\mathrm{X}$-axis: temperature $\left({ }^{\circ} \mathrm{C}\right)$. The graph shows three genetic materials of each genotype.

The HRM analysis has the disadvantage of its sensitivity to the residues of different DNA extraction methods, which may lead to melting curves with subtle differences that, in some cases, may cause an increase in the number of false positives (White and Potts, 2006). This was seen in the 6 groups from different dairy farms, maybe due to the fact that DNA was extracted by different operators or laboratories. Nevertheless, low quality samples can be easily identified and excluded from subsequent analyses if the PCR reaction is subjected to real time monitoring. Hence, for a HRM reaction, it is necessary to use the same bleeding (for fresh or coagulated blood) and DNA extraction procedures for all the samples.

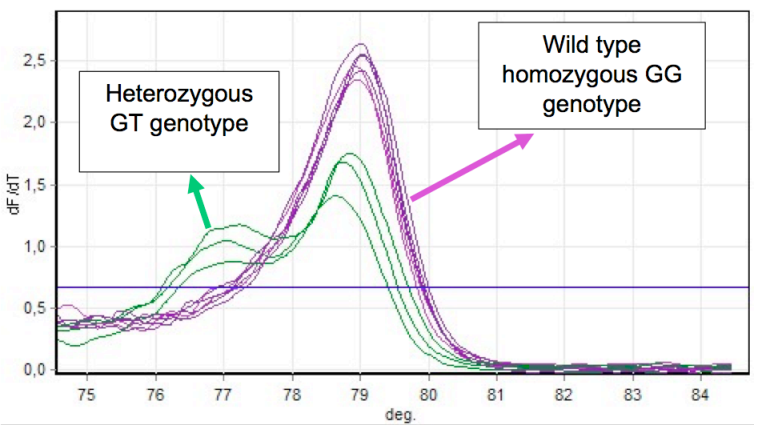

Figure 3. Negative derivative of the fluorescence melting curves at temperature $(-d F / d T)$ for the homozygous wild type (GG) and heterozygous (GT) genotypes. The graph shows the material of three heterozygous (GT) and six homozygous (GG) genotypes.

The comparisons of the shapes and difference graphs of the melting curves of negative derivatives $(-d T / d F)$ allowed the detection of two different CVM genotypes. CVM carriers (GT genotypes) were detected by two peaks for each $\mathrm{G}$ and $\mathrm{T}$ allele (78.75 and 77.05 ${ }^{\circ} \mathrm{C}$ respectively). In Gabor et al. (2012a), the melting point of the CVM carriers was lower than that of non-carrier animals $\left(78.15{ }^{\circ} \mathrm{C}\right.$ and $79.42{ }^{\circ} \mathrm{C}$, respectively). HRM analysis permits to detect single base variations by comparing the melting curves of PCR products with the selection curve of a reference or control sample. The main advantages of HRM analysis when compared with gel-based methods are its lower cost, minimal labor, lesser time, 
and reduction of the risk of contamination of the PCR reaction, the latter due to the fact that, unlike digestion with restriction enzymes or gel visualization, in HRM analysis it is not necessary to manipulate the sample after PCR (Tindall et al., 2009).

This study optimized the HRM analysis protocol as a simple, fast, and reliable genotyping method for CVM disease in Holstein cattle. The first step consisted in finding the control samples for the CVM mutation in the SLC35A3 gene. A preliminary HRM analysis with 25 DNA samples detected 3 control samples carriers of the mutation for the corresponding gene. As there were no CVM positive controls (sick homozygous), we used the ArBos1 genotyping service for identification and isolation of control samples carriers of the CVM mutation, these samples with known genotypes were used as controls for the HRM analysis. The need of using an alternative genotyping method before HRM is one of the main limitations of the PCR-HRM technique. In addition, primers were selected from those amplicons with the smallest possible size. For this study we used the primers used in ZhiLing et al. (2015) for real-time PCR with TaqMan probes: the $79 \mathrm{bp}$ long amplicon amplified for the HRM analysis described in this study. The GC content of the forward and reverse primers used in this study ranged between 40 and $60 \%$; this was a proper content (45.5 and $47.8 \%$, respectively), as neither non-specific amplifications nor primer dimers were observed; thus validating the primer design of ZhiLing et al. (2015) for HRM analysis. The reduction of amplicon size increases the difference of the signal emitted at a given temperature between two sequences differing in just one nucleotide position. Genotypic differences are more clearly visible with smaller amplicons (Gundry et al., 2003).
Heterozygotes can be identified by a modification in the shape of the melting curve, while homozygotes are identified by a modification in the melting temperature (Tm) (Liew et al., 2004).

Both the 3 DNAs of the heterozygous genotype (carrier of the mutation) and the 22 DNAs of the wild type homozygous genotype were confirmed by genotyping with the ArBos1 50K SNP panel; these were used as controls for carriers of the mutant allele for assignation of genotypes in HRM analyses with the Rotor-Gene $Q$ program. Both the genotyping data of ArBos1 and the HRM analyses of the SLC35A3 gene confirmed the assigned genotype for all samples. The single site mutation of gene SLC35A3 influences the melting pattern (Tm) of PCR products, generating different high resolution melting curves that permit genotype differentiation and identification by HRM analysis.

In 18 cows of the analyzed sample, it was detected a mutant CVM allele (T) (c.559G>T; SLC35A3), with a confidence interval greater than $90 \%$. These results obtained are shown in Table 1. As a first report for molecular diagnosis of CVM, this study found a high frequency $(q=0.032)$ of the mutant CVM allele (c.559G>T; SLC35A3) in the analyzed sample, with a prevalence of $6.45 \%$ of carrier cows. Both the frequency of the mutant allele and the prevalence of CVM carriers of this study were high when compared with those of the cows of Turkey $(q=0.01$ and $3.4 \%$, respectively, Meydan et al., 2010). Nevertheless, the prevalence was low when compared with other countries, such as Denmark (31.0\%, Thomsen et al. 2006), Poland (24.8\%, Rusc and Kaminski, 2007), Japan (32.5\%, Nagahata et al., 2002), Sweden (23.0\%, Berglund et al., 2004), and Germany (13.2\%, Konersmann et al., 2003). The 
reason for these differences may be due to the fact that there are samples from different populations, that is, cattle from different regions, although it may also be influenced by the use, over time, of semen from bulls carriers of the mutation. Approximately since the turn of the century, most countries have developed improvement programs to decrease the frequency of CVM carriers in the cattle population (Rusc and Kaminski, 2007). Nevertheless, In Japan, Ghanem et al. (2008) found 26 CVM carriers in 200 Holstein cows (13.0 $\%)$. Hence, the frequency of CVM carriers seems to continue to be high in some Holstein populations.

Table 1 - Number of carriers, distributions of mutant allele frequency, and prevalence of complex vertebral malformation carriers in the six sampled farms of different regions of Uruguay.

\begin{tabular}{ccccc}
\hline Farm & $\begin{array}{c}\text { Sample size } \\
\text { (call rate } \\
>\mathbf{0 . 9 0 )}\end{array}$ & $\begin{array}{c}\text { Number } \\
\text { of } \\
\text { carriers }\end{array}$ & $\begin{array}{c}\text { Prevalence of } \\
\text { carriers (\%) }\end{array}$ & $\begin{array}{c}\text { Mutant allele } \\
\text { frequency (q) }\end{array}$ \\
\hline "A" & 56 & 7 & 12.5 & 0,063 \\
"V" & 63 & 7 & 11.11 & 0,056 \\
"L" & 63 & 1 & 1.59 & 0,008 \\
"G" & 16 & 2 & 12.5 & 0,063 \\
"M" & 28 & 0 & 0 & 0,000 \\
"B" & 53 & 1 & 1.89 & 0,009 \\
\hline TOTAL & $\mathbf{2 7 9}$ & $\mathbf{1 8}$ & $\mathbf{6 . 4 5}$ & $\mathbf{0 , 0 3 2}$ \\
\hline
\end{tabular}

In this study, the first report on CVM in Uruguay, it was possible to clearly identify two different genotypes for the CVM mutation (c.559G $>\mathrm{T}$; SLC35A3) with the PCR-HRM procedure, thus validating it for genotyping in cattle.

\section{CONCLUSIONS}

The PCR-HRM analysis here in described provides an alternative approach for genotyping of mutant alleles in cattle. The HRM application is a fast, easily interpretable, low-cost, and highly precise procedure for the detection of the mutant allele $(T)$ of gene SLC35A3, allowing the genotyping of great volumes of cattle for the CVM disease. The high prevalence of CVM carriers observed in the reference population of Uruguayan Holstein cattle justifies the need of implementing strategies for a gradual elimination of the mutant disease in dairy herd.

\section{ACKNOWLEDGMENTS}

The results of this publication are part of the research funded by the Agencia Nacional de Investigación e Innovación of Uruguay under code POS_NAC_2017_1_141239.

Genotyping of the ArBos1 was financed by the Unidad de Biotecnología of INIA Las Brujas (through Marco Dalla Rizza, PhD) and the Plataforma de Salud Animal of INIA La Estanzuela (Federico Giannitti, PhD). To BS Beatriz Carracelas, of the Banco de ADN Genómico Animal of INIA Las Brujas, for assisting with the access and supply of the DNA samples of the Holstein cows. To Pablo Mones, B.S. in Biology \& BA in Translation, for the translation into English. 


\section{REFERENCES}

AGERHOLM, J.S. Inherited disorders in Danish cattle. APMIS Supplementum, v.115, n.122, p.1-76, 2007.

AGERHOLM, J.S.; BENDIXEN, C.; ANDERSEN, O. et al. Complex vertebral malformation in Holstein calves. Journal of Veterinary Diagnostic Investigation, v.13, p.283-289, 2001.

AGERHOLM, J.S.; BENDIXEN, C.; ARNBJERG, J. et al. Morphological variation of "complex vertebral malformation" in Holstein calves. Journal of Veterinary Diagnostic Investigation, v.16, p.548-553, 2004.

BERGLUND, B.; PERSSON, A.; STALHAMMAR, $H$. Effects of complex vertebral malformation on fertility in Swedish Holstein cattle. Acta Veterinaria Scandinavica, v.45, p.161165, 2004.

CHU, Q.; SUN, D.; YU, Y. Identification of complex vertebral malformation carriers in Chinese Holstein. Journal of Veterinary Diagnostic Investigation, v.20, p.228-230, 2008.

CITEK, J.; REHOUT, V.; HAJKOVA J. et al. Monitoring of the genetic health of cattle in the Czech Republic. Veterinární medicína, v.51, p.333-339, 2006.

DUNCAN, R.B.; CARRIG, C.B.; AGERHOLM, J.S. et al. Complex vertebral malformation in a Holstein calf: Report of a case in the USA. Journal of Veterinary Diagnostic Investigation, v.13, p.333-336, 2001.

FEDERICI, M.T.; BRANDA SICA, A.; ARTIGAS, $R$. et al. High-resolution melting (HRM) curve análisis: New approach used to BLAD and DUMPS in Uruguayan Holstein breed. Archives of Veterinary Science, v.23, n.4, p.01-09, 2018. a.- GABOR, M.; MILUCHOVA, M.; ANNA, T. et al. Detection of complex vertebral malformation carriers in Slovak Holstein cattle by high resolution melting analysis. Acta Veterinaria, v.62, p.239248, 2012.

b.- GABOR, M.; TRAKOVICKA, A.; MILUCHOVA, $M$. et al. The use of high resolution mlting for detection of the CAPN530 polymorphism in slovak simental bulls. Journal of Animal Science and Biotechnology, v.45, p.155-159, 2012.

GHANEM, M.E.; AKITA, M.; SUZUKI, T. et al. Complex vertebral malformation in Holstein cows in Japan and its inheritance to crossbred F1 generation. Animal Reproduction Science, v.103, p.348-354, 2008.

GUNDRY, C.N.; VANDERSTEEN, J.G.; REED, G.H. et al. Amplicon melting analysis with labeled primers: a closedtube method for differentiating homozygotes

heterozygotes. Clinical Chemistry, v.49, p.396-406, 2003.

HUNG, C.C.; LEE, C.N.; CHANG, C.H. et al. Genotyping of the G1138A mutation of the FGFR3 gene in patients with achondroplasia using highresolution melting análisis. Clinical Biochemistry, v.41, p.162-166, 2008.

KEARNEY, J.F.; AMER, P.R.; VILLANUEVA, B. Cumulative discounted expressions of sire genotypes for the complex vertebral malformation and beta-casein loci in commercial dairy herds. Journal of Dairy Science, v.88, p.4426-4433, 2005.

KONERSMANN, Y.; WEMHEUER, W.; BRENIG, B. Herkunft, verbreitung und bedeutung des CVM gendefekts in der Holstein Friesian population. Züchtungskd, v.75, p.9-15, 2003.

LIEW, M.; PRYOR, R.; PALAIS, R. et al. Genotyping of single-nucleotide 
polymorphisms by high-resolution melting of small amplicons. Clinical Chemistry, v.50, p.1156-1164, 2004.

MILLER, S.A.; DYKES, D.D.; POLESKY, H.F. A simple salting out procedure for extracting DNA from human nucleated cells. Nucleic Acids Research, v.12, p.319-325, 1988.

MONTGOMERY, J.; WITTWER, C.T.; PALAIS, R. et al. Simultaneous mutation scanning and genotyping by highresolution melting análisis. Clinical Chemistry, v.50, p.1748-1754, 2004.

NAGAHATA, H.; OOTA, H.; NITANAI, A. et al. Complex vertebral malformation in a stillborn Holstein calf in Japan. Journal of Veterinary Medical Science, v.64, p.1107-1112, 2002.

$\mathrm{NEI}, \mathrm{M}$. Molecular Evolutionary Genetics. Nueva York, Columbia University Press, 1987. 512 p.

ONLINE MENDELIAN INHERITANCE IN ANIMALS. Faculty of Veterinary Science, University of Sydney, 2011. Available in: http://omia.angis.org.au/

REED, G.H.; KENT, J.O.; WITTWER, C.T. High-resolution DNA melting analysis for simple and efficient molecular diagnostics. Pharmacogenomics, v.8, p.597-608, 2007.

REVELL, S. Complex vertebral malformation in a Holstein calf in the UK. Veterinary Record, v.149, p.659-660, 2001.

RUSC, A.; KAMINSKI, S. Prevalence of complex vertebral malformation carriers among Polish Holstein Friesian bulls. Journal of Applied Genetics, v.48, p.247-252, 2007.

SANTOS, S.; MARQUES, V.; PIRES, M. et al. High resolution melting: improvements in the genetic diagnosis of hypertrophic cardiomiopathy in a Portuguese cohort. BMC Medical Genetics, v.13, n.17, p.1.13, 2012.
THOMSEN, B.; HORN, P.; PANITZ F. et al. $A$ missense mutation in the bovine SLC35A3 gene, encoding a UDP-N-acetylglucosamine transporter, causes complex vertebral malformation. Genome Research, v.16, p.97-105, 2006.

TINDALL, E.; PETERSEN, D.; WOODBRIDGE, P. et al. Assesing highresolution melt curve analysis for accurate detection of gene variants in complex DNA fragments. Human Mutation, v.30, p.876-883, 2009.

VANRADEN, P.M.; OLSON, K.M.; NULL D.J. et al. Harmful recessive effects on fertility detected by absence of homozygous haplotypes. Journal of Dairy Science, v.94, p.6153-6161, 2011.

VORKAS, P.A.; CHRISTOPOULOS, K.; KROUPIS, C. et al. Mutation scanning of exon 20 of the BRCA1 gene by highresolution melting curve analysis. Clinical Biochemistry, v.43, p.178-185, 2010.

VOSSEN, R.H.; ATEN, E.; ROOS, A. et al. High-resolution melting analysis (HRMA): more than just sequence variant screening. Human Mutation, v.30, p.860-866, 2009.

WHITE, H; POTTS, G. Mutation scanning by high resolution melt análisis. Evaluation of Rotor-Gene 6000 (Corbett Life Science), HR-1 and 384 well LightScanner (Idaho Technology).

National Genetics Reference Laboratory (Wessex, 2006). (http://www.ngrl.org.uk/Wessex/downloa ds.htm)

WINDSOR, P.A.; AGERHOLM, J.S. Inherited diseases of Australian Holstein-Friesian cattle. Australian Veterinary Journal, v.87, p.5, 2009.

WITTWER, C.T.; REED, G.H.; GUNDRY, C.N. et al. High-resolution genotyping by amplicon melting analysis 
using LCGreen. Clinical Chemistry, v.49, p.853-860, 2003.

WOUDA, W.; VISSER, I.J.; BORST, G.H. et al. Developmental anomalies in aborted and stillborn calves in The Netherlands. Veterinary Record, v.147, p. 612, 2000.

ZHILING, L.; XIAOWEI, W.; WEI, K. et al. Establishment and application of TaqMan real-time PCR to detect the complex vertebral malformation in Holstein cattle. Journal of South China Agricultural University, v.36, n.5, p.2630, 2015. 